\title{
POŚTA
}

TELEKOMUNIKÁCIE A

ELEKTRONICKY OBCHOD

\section{INFORMAČNÉ A ASISTENČNÉ SLUŽBY SLOVAK TELECOMU, A.S.}

\section{Margita Majerčáková*}

Medzi očakávania zo strany prevádzkovatel'ov služieb patrí získanie nových zákazníkov, udržanie doterajších zákazníkov, zvýšenie ich spokojnosti a dosiahnutie konkurenčných výhod.

Spoločnost' Slovak Telecom, a.s. prevádzkuje pre poskytovanie informačných a asistenčných služieb D\&AS Centrum (Directory and Assistance Services) Jeho hlavným portfóliom je poskytovanie informácií o telefónnych číslach na Slovensku a v zahraničí [1].

D\&AS Centrum vzniklo $\mathrm{z}$ dôvodu účinnejšieho poskytovania informácii zákazníkom. Zákazník očakáva správne podanie informácie, príjemný spôsob obsluhy, nepretržitý prístup k službám 24 hodín denne 7 krát v týždni. Nové technologické trendy umožňujú poskytnutie informácie v čo najkratšom čase.

V D\&AS Centre nejde iba o poskytnutie informácií ale o poskytnutie informácií čo najkvalitnejšie a najefektívnejšie nielen cez telefón ale aj cez fax a mail. Kvalita centra je zabezpečovaná aj kvalitne pripravenými a skúsenými agentmi s ich komunikačnými schopnost'ami.

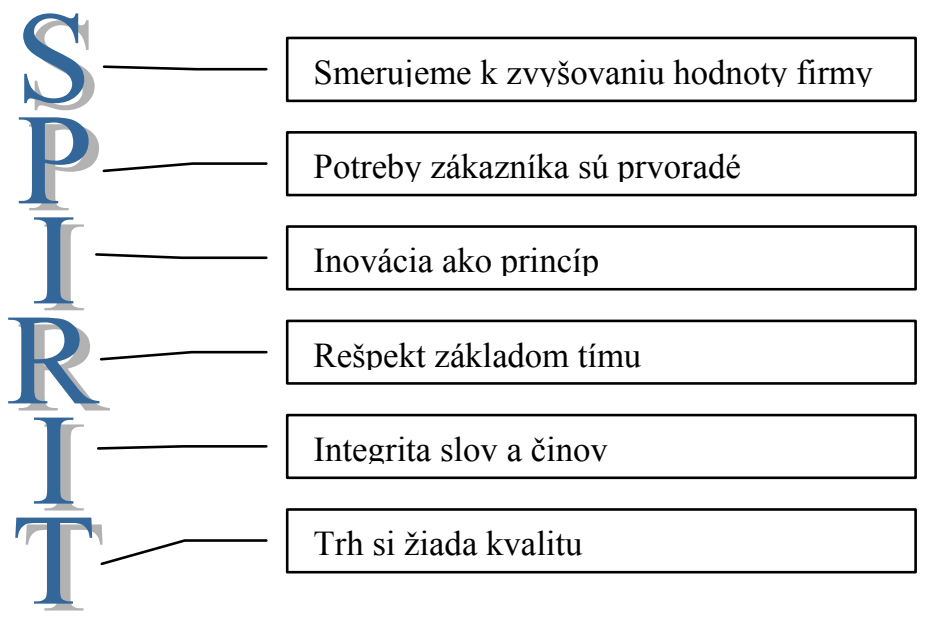

D\&AS Centrum je pomerne nový a pre mnohých neznámy pojem, u nás nahrádzaný skratkou DAS.

Pri kvalitnej starostlivosti o zákazníka je dôležitý prvý - priamy kontakt so zákazníkom, ktorý závisí od komunikácie agentov, ich komunikačných a vyhl’adávacích

\footnotetext{
* Dr. Ing. Margita Majerčáková, Katedra spojov, Fakulta prevádzky a ekonomiky dopravy a spojov, Žilinská univerzita v Žiline, Univerzitná 1, 01026 Žilina, Slovenská republika, tel.: +421415133126 , fax: +421415655615 e-mail: Margita.Majercakova@fpedas.utc.sk
} 
schopnosti. Skvalitnenie prvého - priameho kontaktu agenta so zákazníkom sa dosahuje formou individuálneho coachingu, školení, spätnou väzbou a mystery volaniami [2].

Základné pravidlá správania, ktoré platia pre celú spoločnost' Slovak Telecom a.s. sa musia dodržiavat' aj v DAS Centrách a sú definované vo firemných hodnotách - SPIRIT [1].

V minulosti služby DAS Centra nahrádzali informačné služby, ktoré sme poznali pod názvom ,informačka“. Boli to bezplatné čísla 120 a 0149. Dňa 13. 12. 2003 bola odštartovaná nová etapa Informačných služieb na číslach 1181 a 12149 s novým systémom v DAS Centrách v Bytči a v Košiciach. Tieto služby sú spoplatňované samostatnou tarifou.

Volania na informačné služby 1181 trvajú pre takmer 40\% zákazníkov do 30 sekúnd. Do operátorských a asistenčných služieb patrí aj volanie cez operátora, vnútroštátne a medzinárodné volanie cez operátora, konferenčné hovory, budenie telefónom, presný čas, Slovakia Direct.

Virtuálne DAS Centrá v Bytči a v Košiciach pracujú na rovnakej báze, s rovnakým plánovaním, platia pre ne rovnaké kritériá pokial' ide o kvalitu i kvantitu. Hovory sú nasmerované k prvému vol’nému agentovi či už je v Bytči alebo v Košiciach.

\section{Služby DAS}

\section{- $\quad$ Služba 1181}

Táto služba poskytuje telefónne čísla na území SR. Je rozšírená o ponuku spojenia na vyhl'adané číslo, odoslanie vyhl'adaného čísla prostredníctvom faxu alebo emailu, o spätné vyhl'adanie pomocou telefónneho čísla a o informácie o telefónnych číslach zákazníkov Eurotelu. Informácie poskytované na čísle 1181 sa aktualizujú každý deň, aby sa zabezpečila ich správnost' a presnost' [3].

\section{- $\quad$ Služba 12149}

Táto služba poskytuje informácie o telefónnych číslach v zahraničí. Pri tejto službe je možnost' prepojenia na vyhl'adané číslo (podmienkou prepojenia je, že účastník musí volat' z pevnej linky), možnost' zaslat' informácie faxom alebo e - mailom, nie je tu možnost' spätného vyhl'adávania.

- $\quad$ Služba 12111

Od 1. novembra 2004 existuje nové číslo pre nové informácie, ktoré sú poskytované prostredníctvom operátorov DAS Centier. Informácie sú čerpané z rôznych webových stránok na základe zmluvného vzt’ahu s ich majitel'mi. Služba na čísle 12111 sa nazýva Info Asistent, na tomto čísle sú poskytované informácie z rôznych oblastí:

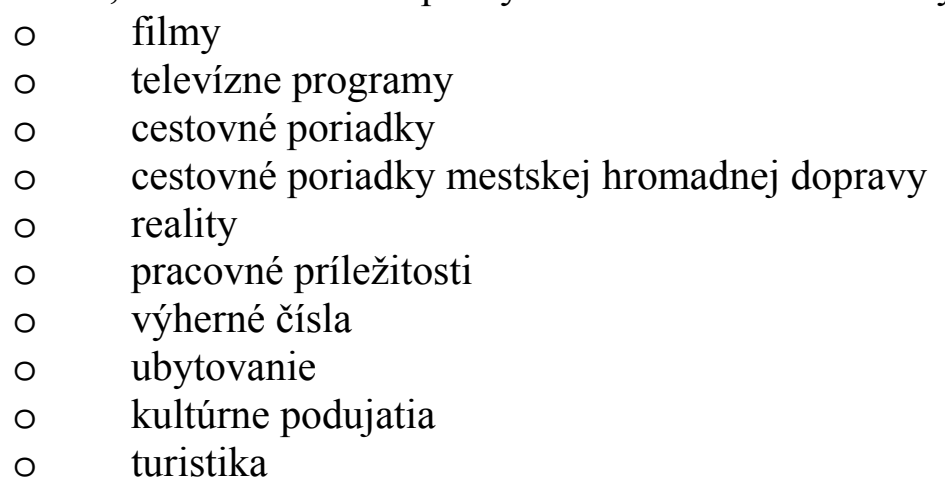

- $\quad$ Služba 12127 -služba zabezpečuje podávanie telegramov

- Služba ANA - automatické oznamovanie čísla (Na službe 1181 a 12149), to znamená, že hláska automatického systému prezentuje zákazníkovi požadované telefónne číslo. Systém oznamuje telefónne číslo dvakrát. Nakoniec je v rámci automatického oznámenia čísla zákazníkovi ponúknutá možnost' zostat' na linke na získanie d’alších informácií a byt' prepojený $\mathrm{k}$ najbližšiemu vol’nému operátorovi. 


\section{Informačné systémy a technológie v DAS Centre}

DAS Centrum nie je len telefonický kontakt so zákazníkom, ale integruje aj všetky dostupné komunikačné kanály. Technológia DAS Centra vyberie prvého vol'ného agenta a zabezpečí podanie potrebnej informácie.

Systémy využívané v DAS Centre

- ID (Intelligent Department) - je kompatibilné, vysoko funkčné DAS Centrum, vybudované na báze technológie CTI. Znamená integráciu rôznych komponentov, akými sú: automatický hlasový systém IVR, integrácia počítačovej a telefónnej siete CTI a automatická distribúcia hovorov ACD.

- ACD (Automatic Call Distribution) - Automatické triedenie hovorov. Zabezpečuje automatické rozdel'ovanie hovorov prichádzajúcich do DAS Centra, ktoré umožňuje rovnomerné zat'aženie agentov volaniami. ACD rozdel'uje prichádzajúce hovory podl'a dížky čakania, obsadenosti či vyt'aženosti agentov.

- IVR (Interactive Voice Responce) - Automatické hlasové systémy. Zabezpečujú hromadné spracovávanie prichádzajúcich hovorov. Poskytujú a zbierajú informácie a vykonávajú rôzne funkcie v závislosti od zložitosti súvisiacich informačných systémov. V plnej miere využívajú DTMF pre spoluprácu s volajúcim.

- DTMF (Dual Tone Multi Frequency) je základnou podmienkou fungovania hlasových systémov, kde jednotlivé položky menu predstavujú vol'by čísel na klávesnici telefonného aparátu. Každé číslo je reprezentované dvojicou tónov a zvolením príslušného čísla dokáže volajúci ovládat' hlasový systém.

- CTI (Computer Telephony Integration) - Integrácia telekomunikačných zariadení a informačných technológií. Systém zabezpečujúci prepojenie na informačný systém, napr. vd’aka ktorému je volajúci zákazník identifikovaný a jeho dáta sa zobrazia na monitore agenta.

\section{Aplikácie používané v DAS Centre}

Varetis (VStation) - aplikácia, ktorá je základný pracovným nástrojom operátorov umožňujúca agentom vyhl'adávat' v dostupných databázach obsahujúcich údaje o telefónnych číslach na základe zadaných vyhl'adávacích kritérií a následne vyhl'adané číslo zákazníkovi poskytnút' prostredníctvom niektorej z poskytovaných služieb:

- ANA - automatické oznámenie telefónneho čísla

- Call Completion - automatické prepojenie na vyhl'adané číslo

- Poslanie informácie faxom alebo mailom

- VOČ - verbálne oznámenie čísla

- CLI ( Call line identifier ) - skratka pre označenie koncového telefónneho čísla. Slúži pre štatistiku.

- CTI (počítačovo-telefonická integrácia) - zastrešuje funkčnost' Call Completion, ANA, prepájanie sa do prestávky a z prestávky atd'. V prípade nefunkčnosti ani jedna zo spomenutých operácii nefunguje

- Osobná hláska (personal greeting) - uvítacia automatická hláska agenta obsahujúca pozdrav a meno agenta, ktorá sa automatický prehrá po spojení hovoru na agenta ( nefunguje v prípade nefunkčnosti CTI)

- QST - pomocná databáza obsahujúca všetky doplnkové informácie potrebné predovšetkým pre medzinárodných agentov

- Reconnection - opätovné spojenie účastníka s agentom bez opustenia systému informačnej služby ( účastník ostal na linke po vypočutí ANA, alebo po neúspešnom prepojení) 
Dostupné databázy:

- NDIS (databáza Slovak Telecom a.s.)

- Eurotel Databáza (databáza post paidových zákazníkov spoločnosti Eurotel Bratislava a.s.)

- QST (pomocná informačná databáza)

- Dostupné databázy medzinárodných telekomunikačných operátorov

- Lucent CentreVu Supervisor - aplikácia, slúžiaca na sledovanie prevádzkových ukazovatel'ov:

- v reálnom čase

- historické štatistické údaje - pomocou nich sa sleduje aktuálny stav všetkých agentov (hovor, prestávka...), ich počet, využitel'nost', počet hovorov, dížka hovorov atd'. a to bud' v reálnom čase alebo sa dajú informácie vyhl'adat' aj spätne.

- Siebel - informačný systém, ktorý obsahuje základné informácie o zákazníkoch ST a.s. (fakturačné údaje, produkty, spôsob zverejnenia, objednávky, požiadavky..). Na DAS je využívaný hlavne pre kontrolu telefónnych čísiel v prípade ak sa agent st’ažuje, že je neplatné resp. nefunkčné alebo pri reklamáciách zákazníkov na chybné zverejnenie niektorého z údajov (samotné číslo, názov, adresa) na informačnej službe resp. v tlačenom telefónnom zozname. Taktiež je využívaný pre zadávanie požiadaviek týkajúcich sa vykonania zmien pri niektorom zo zverejnených údajov $\mathrm{v}$ informačnej databáze NDIS.

- MIS (manažérske informačné systémy) - Je možné pracovat' so štatistickými údajmi, ktoré sú zaznamenávané prostredníctvom VStation počas práce každého operátora. Detailne sledujú operácie, ktoré boli uskutočnené. Potom je spätne možné v prípade potreby tieto informácie získat'. Z časového hl'adiska MIS reporty rozlišujeme:

- Short term (krátkodobé) - obsahujú údaje za posledných $8+$ aktuálny deň, pričom údaje sú dostupné aj pre jednotlivé časové intervaly pre každý deň

- Long term (dlhodobé) - obsahujú údaje za posledných $13+$ aktuálny mesiac, pričom sú dostupné súhrnné údaje pre jednotlivé dni

Typy MIS Reportov:

- IOT reporty - slúžia na sledovanie vstupov medzinárodných agentov do zahraničných databáz a tiež vstupy zahraničných agentov do našej databázy.

- MSG reporty - udávajú počet odoslaných faxov a e-mailov a to na konkrétnu štvrthodinu. Informáciu na ktoré Faxové čísla a emailové adresy boli vyhl'adané informácie zasielané.

- OSA reporty - sú tam všetci agenti DAS centra a pri nich sa dá zistit' každá činnost', ktorú vykonali pri vyhl'adávaní ako aj výsledok prečo bolo vyhl'adanie neúspešné

- CTI reporty

- LUS reporty - obsahuje výpis čísel a e-mailových adries ( tých ktoré boli poskytnuté, čísla volajúcich zákazníkov..) 


\section{Kvantitatívne charakteristiky DAS Centra}

Základné kvantitatívne charakteristiky DAS Centra

- Inbound Calls - prichádzajúce hovory

- Outbound Calls - odchádzajúce hovory

- ACD Calls - spracované hovory

- Abandon Calls - spadnuté hovory

- ACD Time - dĺžka hovorov

- ACW Time - čas po hovore

- AVG ACD Time - priemerný manipulačný čas

- Inbound Calls - počet hovorov, ktoré vstúpili do systému danej služby

- ACD Calls - počet hovorov, ktoré boli spojené s operátorom za stanovený časový interval

- Abandon Calls - sú hovory spadnuté, kedy volajúci zloží skôr ako je spojený s agentom.

- ACW Time - agent vykonáva prácu súvisiacu s predchádzajúcim uskutočneným hovorom

\section{Faktory pôsobiace na základné charakteristiky DAS Centra}

Faktory, ktoré pôsobia na kvantitatívne charakteristiky môžeme rozdelit' :

- interné faktory - úroveň technického vybavenia, odborné kvality zamestnancov ich výkonnost', flexibilitu a pod.

- externé faktory - reklamy v médiách, televízne a rozhlasové sút'aže, vplyv dovoleniek, prázdnin a sviatkov, poruchy na linkách, obdobie počas mesiaca.

\section{Kvalitatívne ukazovatele v DAS Centre}

Kvalita je základom fungovania každej organizácie. Predstavuje nástroj získavania a udržiavania si zákazníkov a budovanie ich dôvery. Prispieva k zvyšovaniu imidžu spoločnosti, lojality zákazníkov a výnosov.

Postavenie záujmov zákazníkov na prvé miesto, ako aj zabezpečenie ich spokojnosti je najlepšia cesta, ako ich získat' a zároveň zabezpečit', aby nad’alej zostal „našim“ zákazníkom. Hoci je spokojnost' zákazníkov niečo nehmatatel'né a t’ažko meratel'né, napriek tomu musí byt' kvantifikovaná a sledovaná.

Kvalitatívne ukazovatele DAS Centra

- ukazovatel': Service Level (dostupnost') - percentuálne vyjadruje ako sú obsluhovaní účastníci, závisí od počtu účastníkov, ktorí čakajú v čakacom rade viac než stanovený počet sekúnd a od počtu padnutých hovorov.

- ukazovatel': Abandon Rate - počet hovorov, ktoré boli ukončené skôr ako boli spojené s agentom

- ukazovatel': WQ-waiting queue (čakací rad) - počet účastníkov, ktorí čakajú v systéme na vol'ného agenta

- ukazovatel': ACW (After Call Work alebo Wrap up time) - agent vykonáva prácu súvisiacu s predchádzajúcim uskutočneným hovorom

- ukazovatel': ATT (Average Talk Time) priemerná doba hovoru agenta so zákazníkom

- ukazovatel’: AHT ( Average Handle Time) - priemerná doba čakania zákazníka na spojenie s agentom

- ukazovatel': Oldest Call Waiting - najdlhšie čakajúci hovor

- ukazovatel': Calls per possition - počet hovorov na jedného agenta za časový interval 30 minút 
Pri aplikovaní kvalitatívnych ukazovatel’ov na prevádzke je možné posudzovat' kvalitu z dvoch hl'adísk:

- kvalita je dosiahnutá dobrým pocitom zákazníka. Na sledovanie kvality z tejto stránky používame kvalitatívne parametre, hovoriace o tom, ako dlho zákazník čaká na spojenie s agentom, ako rýchlo je vybavená jeho požiadavka, atd'.

- kvalita hovoru. Kvalitatívnu stránku hovorov zabezpečujú agenti. Ich vyjadrovacia schopnost', verbálny prejav a ústretový prístup k zákazníkovi značne vplývajú na kvalitu hovorov a sú rozhodujúce pri rozhodovaní sa zákazníka, či zavolá do DAS Centra aj v budúcnosti.

\section{Literatúra:}

[1] Interné materiály DAS centra

[2] SmeTu 2/2005, interný časopis ST a.s.

[3] Služby DAS centra, bakalárska práca, ŽU v Žiline, FPEDaS, Katedra spojov, 2005 